\title{
Pengaruh Modal Insani dan Modal Sosial terhadap Kinerja (Studi Kasus Usaha Kecil dan Menengah (UKM) Makanan dan Minuman Kota Bogor)
}

\author{
Layla Khoirrini \\ Departemen Manajemen, Fakultas Ekonomi dan Manajemen \\ Institut Pertanian Bogor \\ Kampus Darmaga Bogor 16680 \\ Lindawati Kartika \\ Departemen Manajemen, Fakultas Ekonomi dan Manajemen \\ Institut Pertanian Bogor \\ Kampus Darmaga Bogor 16680 \\ e-mail: lindawati.kartika@gmail.com
}

\begin{abstract}
Small and Medium Enterprises (SMEs) for foods and beverages cluster at Bogor City are capable of creating jobs. Labor is the assets for the organization in order to develop human capital and social. The purposes of this research are to analyze descriptively and quantitatively the influence of human capital and social capital of SMEs and also to formulate recommendation for sustainable development of SMEs specifically for foods and beverages cluster. This research used several methods, such as : descriptive analysis, Importance Performance Analysis (IPA), fishbone diagram, and Structural Equation Modelling (SEM) with Partial Least Squares (PLS). The result shows that other knowledge and structural dimension has significantly influential to human capital and social capital. Moreover, it was shown that human capital and social capital had positive influence on performance of SMEs. Therefore, some supporting activitives were suggested to improve for SMEs, including formulating a quality control system and developing standard operational procedures of production, infrastructure and assets and also participating in training and development to enhance competencies of SME's employees.

Keywords: human capital, SMEs's performance, social capital, structural equation modelling, partial least squares
\end{abstract}

\begin{abstract}
ABSTRAK
Usaha Kecil dan Menengah (UKM) makanan dan minuman kota Bogor mampu menyerap banyak tenaga kerja. Tenaga kerja merupakan aset bagi perusahaan dalam bentuk modal insani dan modal sosial. Tujuan penelitian ini adalah menganalisis secara deskriptif, menganalisis pengaruh modal insani dan modal sosial terhadap kinerja UKM makanan dan minuman Kota Bogor, serta memformulasikan rekomendasi untuk meningkatkan kinerja UKM. Metode penelitian yang digunakan antara lain analisis deskriptif, Importance Performance Analysis (IPA), fishbone diagram, dan Structural Equation Modelling (SEM) dengan pendekatan Partial Least Squares (PLS). Hasil analisis SEM menyatakan bahwa pengetahuan lain dan dimensi struktural berpengaruh terhadap modal insani dan modal sosial, di mana modal insani dan modal sosial berpengaruh positif dan signifikan terhadap kinerja. Oleh karena itu, peningkatan kinerja pada UKM direkomendasikan melalui beberapa kegiatan penunjang antara lain: membentuk sistem pengendalian mutu dan penyusunan standar pelaksanaan produksi, memperbaiki sarana prasarana yang dimiliki oleh UKM, serta ikut serta dalam pelatihan untuk meningkatkan kompetensi pekerja UKM.
\end{abstract}


Kata kunci: kinerja UKM, modal insani, modal sosial, partial least squares, structural equation modelling

\section{Pendahuluan}

Negara-negara berkembang kini mulai mengubah orientasinya ketika melihat pengalaman di Negara-negara maju tentang peranan dan sumbangan Usaha Kecil dan Menengah (UKM) dalam pertumbuhan ekonomi. Pertumbuhan usaha di Indonesia pun mengalami pertumbuhan tiap tahunnya sehingga UKM memberikan kesempatan kerja yang potensial. Pemerintah kota Bogor merupakan salah satu pemerintahan yang memperhatikan masalah UKM di wilayahnya. Unit UKM di kota Bogor dibagi menjadi dua jenis yaitu formal dan non formal dengan masing-masing jenis usaha berbeda. Usaha formal merupakan usaha yang telah memiliki status hukum dan ijin dari pemerintah dalam mendirikan usahanya.

Total unit usaha makanan dan minuman memiliki total unit usaha industri sebanyak 342 yang merupakan jumlah terbesar dibanding sektor lainnya seperti kayu olahan, bahan kimia, logam, alat angkut, industri tekstil, industri alpora, pulp, dan industri kulit. Selain itu, UKM makanan dan minuman pun mampu menyerap tenaga kerja sebanyak 6034 orang (Disperindag Kota Bogor 2009). Hal ini membuktikan bahwa industri makanan dan minuman berpotensi besar untuk dikembangkan. Kondisi cuaca di Bogor pun mendukung para pelaku usaha untuk mendirikan usaha kecil dan menengah. Melihat adanya peluang mendapatkan keuntungan, saat ini masyarakat berlomba-lomba menginvestasikan uangnya dalam bentuk UKM. Dengan demikian, jumlah UKM kota Bogor pun mengalami peningkatan dalam kurun waktu lima tahun.

Pada usaha kecil jumlahnya mengalami peningkatan tiap tahunnya sehingga pada tahun 2013 mencapai 5155 unit usaha. Namun, pada usaha menengah terjadi penurunan jumlah unit usaha dari tahun 2011 ke tahun 2012 yaitu 1679 unit menjadi 1477 unit. (Dinas Koperasi dan UMKM Kota Bogor 2013). Penurunan jumlah unit usaha menengah diduga adanya kenaikan potensi usaha menjadi usaha besar. Menurut Tambunan (2009), pada usaha menengah sebagian besar pemilik usaha telah berpendidikan baik, memiliki akses program pemerintah, dan sudah memperkerjakan manajer profesional. Hal tersebut menandakan bahwa usaha menengah memiliki modal insani yang baik. Selain itu, telah terbentuknya manajemen dan struktur organisasi formal pada usaha menengah mempresentasikan modal sosial yang baik pula. Oleh karena itu, tenaga kerja atau sumberdaya manusia disebut sebagai intangible asset. Intangible asset ini dapat direpresentasikan melalui modal insani dan modal sosial.

Penelitian Stam dan Elfring (2008) memfokuskan peran jejaring intra dan ekstra industri sebagai salah satu unsur pembentuk modal social. Penelitian ini membuktikan bahwa modal sosial merupakan media mediasi yang memperkuat hubungan antara orientasi entrepreneur dengan kinerja. Nahapiet dan Goshal (1998) menyatakan bahwa indikator untuk modal sosial yaitu dimensi struktural, relasional dan kognitif. Hasil penelitian Wahyuningrum (2013) memperlihatkan bahwa modal insani dan modal sosial memiliki pengaruh langsung terhadap kinerja pada UKM Kerajinan di Depok. Kedua penelitian terdahulu telah membuktikan bahwa kinerja dipengaruhi oleh modal insani atau modal sosial. Namun, belum ada penelitian yang menyatakan bahwa 
modal insani dan modal sosial berpengaruh terhadap kinerja pada UKM cluster makanan dan minuman kota Bogor.

Perumusan masalah pada penelitian ini adalah : 1) Bagaimana persepsi mengenai modal insani, modal sosial dan kinerja di UKM Makanan dan Minuman Kota Bogor?; 2) Bagaimana hasil analisis pengaruh antara modal insani dan modal sosial terhadap kinerja UKM Makanan dan Minuman Kota Bogor?; 3) Apakah model terbaik untuk meningkatkan kinerja UKM Makanan dan Minuman Kota Bogor?

Tujuan penelitian ini adalah : 1) Menganalisis secara deskriptif mengenai modal insani, modal sosial dan kinerja di UKM makanan dan minuman Kota Bogor; 2) Menganalisis pengaruh modal insani dan modal sosial terhadap kinerja UKM makanan dan minuman Kota Bogor; 3) Memilih model terbaik untuk meningkatkan kinerja UKM makanan dan minuman Kota Bogor.

\section{Metode Penelitian}

Pada tahap awal dianalisis secara deskriptif mengenai UKM makanan dan minuman. Selanjutnya, menganalisis tingkat kepentingan antara kinerja yang dicapai dengan metode Importance Performance Analysis (IPA) dan mengidentifikasi permasalahan yang ada di UKM dengan analisis tulang ikan (fishbone chart). Tahap berikutnya, menentukan pengaruh dari modal insani dan modal sosial terhadap kinerja pada UKM makanan dan minuman Kota Bogor. Alur penelitian dijelaskan pada Gambar 1.

Penelitian dilaksanakan di UKM Agro Kota Bogor sejak Juli hingga Oktober 2013. Data yang digunakan dalam penelitian ini terdiri dari data primer dan data sekunder. Pemilihan populasi UKM makanan dan minuman di Bogor berdasarkan kriteria: terdaftar di Dinas Perindustrian dan Perdagangan (Disperindag) dan Dinas Koperasi dan UMKM Kota Bogor, memiliki minimum 5 orang pekerja, pemilik aktif mengikuti pelatihan dari dinas terkait, dan UKM yang dinilai mampu untuk menerapkan pelatihan. Dengan demikian, didapatkan jumlah populasi sebanyak 65 unit usaha. Menurut Umar (2003) pengambilan ukuran sampel jika populasi relatif kecil, maka ukuran sampel minimum 20\% dari populasi. Diperoleh 13 UKM yang diteliti. Teknik pengambilan sampel dengan menggunakan metode non-probabilitas dengan cara purposive sampling yaitu pemilihan sampel berdasarkan pada kriteria tertentu yang dianggap mempunyai sangkut paut dengan karakteristik populasi. Adapun sampel karyawan berasal dari 13 UKM, sehingga diperoleh 65 karyawan. 


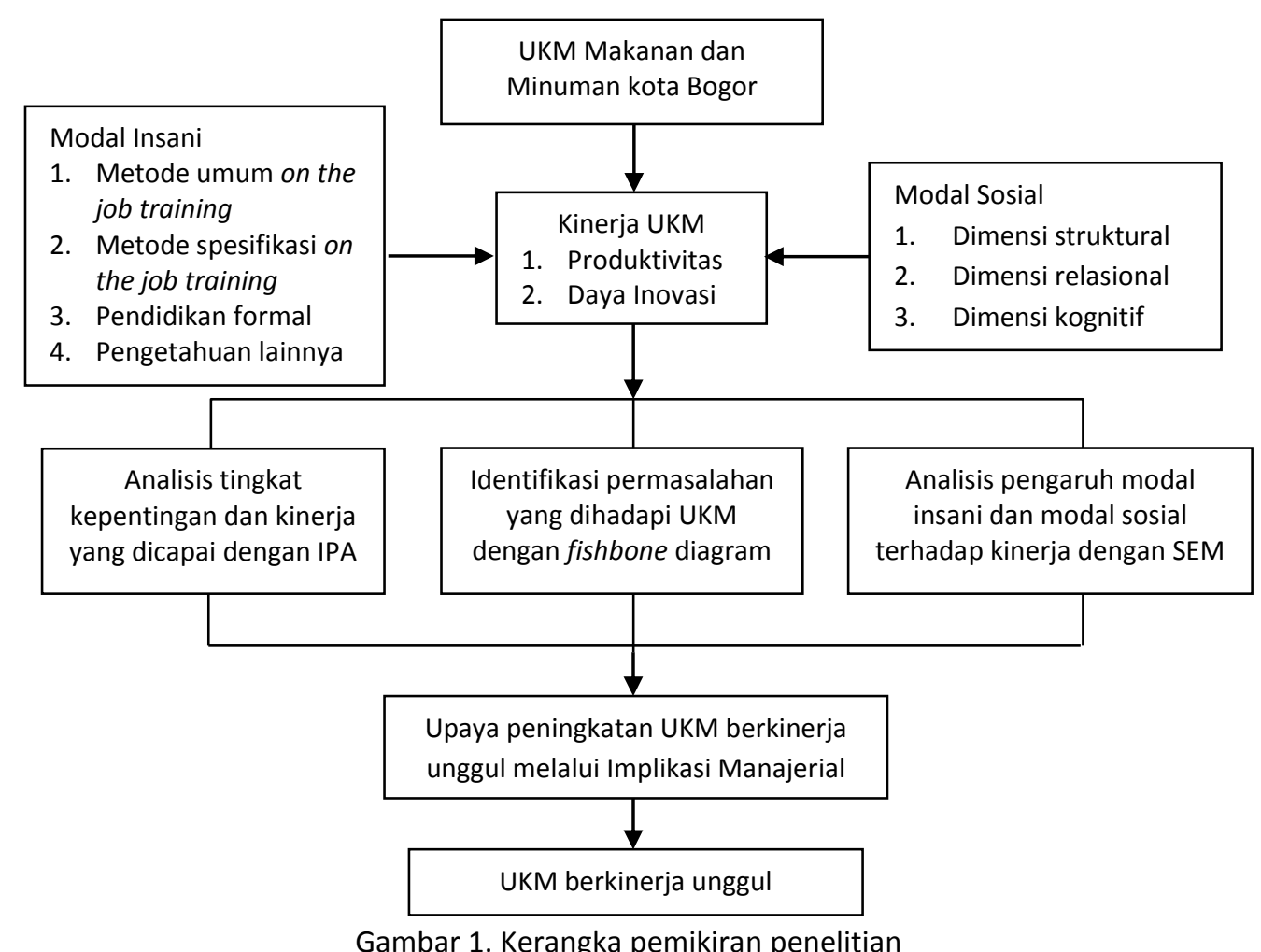
berikut :

Metode analisis data yang digunakan dalam penelitian ini dijabarkan sebagai

1. Analisis Deskriptif

Analisis ini berisi tentang bahasan secara deskriptif mengenai tanggapan yang diberikan responden pada kuesioner. Penilaian yang telah ditetapkan antara 1 hingga 5 dibuat rentang skala. Berdasarkan hasil persamaan dan bobot nilai yang digunakan dalam penelitian ini, maka diperoleh rentang skala 0.8 .

2. Analisis Kepentingan-Kinerja/Importance Performance Analysis (IPA)

Teknik analisis kepentingan-kinerja responden diminta untuk memeringkatkan berbagai elemen (atribut) dari penawaran berdasarkan derajat pentingnya setiap elemen tersebut. Selain itu, responden juga diminta memeringkatkan kinerja perusahaan dalam masing-masing elemen/atribut tersebut.

3. Fishbone Diagram

Fishbone diagram adalah suatu pendekatan terstruktur yang memungkinkan dilakukan suatu analisis lebih terperinci dalam menemukan penyebab-penyebab suatu masalah, ketidaksesuaian, dan kesenjangan yang ada (Nasution 2001).

4. Structural Equation Modelling (SEM)

SEM adalah persamaan regresi ganda dengan tujuan menguji model pengukuran dan model struktural. Model pengukuran menjelaskan prediksi atau hipotesis hubungan antara variabel penyebab terhadap variabel akibat. Sementara model struktural menjelaskan operasionalisasi variabel penelitian menjadi indikator-indikator terukur yang dinyatakan dalam bentuk diagram jalur (Kusnedi 2008). Pendekatan yang digunakan dalam penelitian ini adalah Partial Least Squares (PLS). 
Pada penelitian ini dilihat pengaruh antara variabel dalam dua bentuk model. Penelitian Stam dan Elfring (2008) memfokuskan peran jejaring intra dan ekstra industri sebagai salah satu unsur pembentuk modal sosial, dapat membuktikan modal sosial merupakan media mediasi yang memperkuat hubungan antara orientasi entrepreneur dengan kinerja. Oleh karena itu, model pertama membuktikan bahwa modal insani berpengaruh langsung terhadap kinerja dan modal sosial sebagai variabel moderator. Model pertama akan dijelaskan pada Gambar 2.

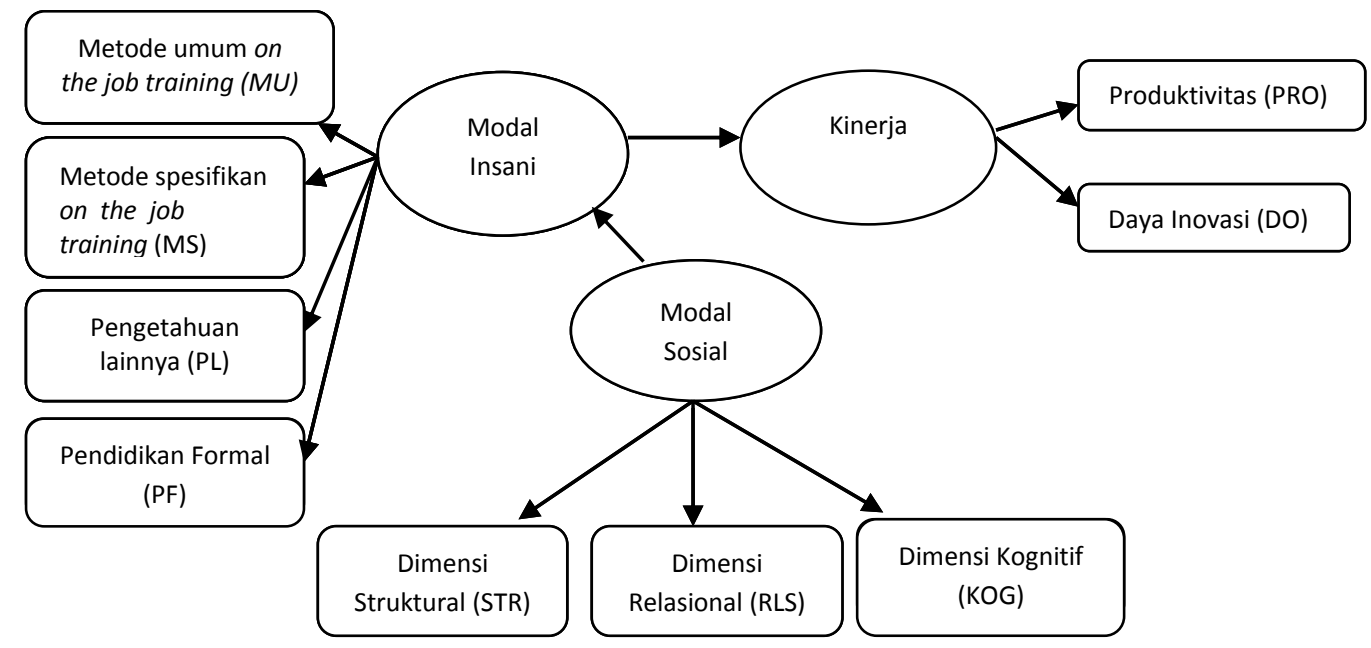

Gambar 2. Struktur model pertama

Pada penelitian sebelumnya (Wahyuningrum 2013) dijelaskan bahwa modal insani dan modal sosial memiliki pengaruh langsung terhadap kinerja. Oleh karena itu, model kedua dibuat untuk menunjukan pengaruh langsung modal sosial dan modal insani terhadap kinerja yang ditunjukan pada Gambar 3.

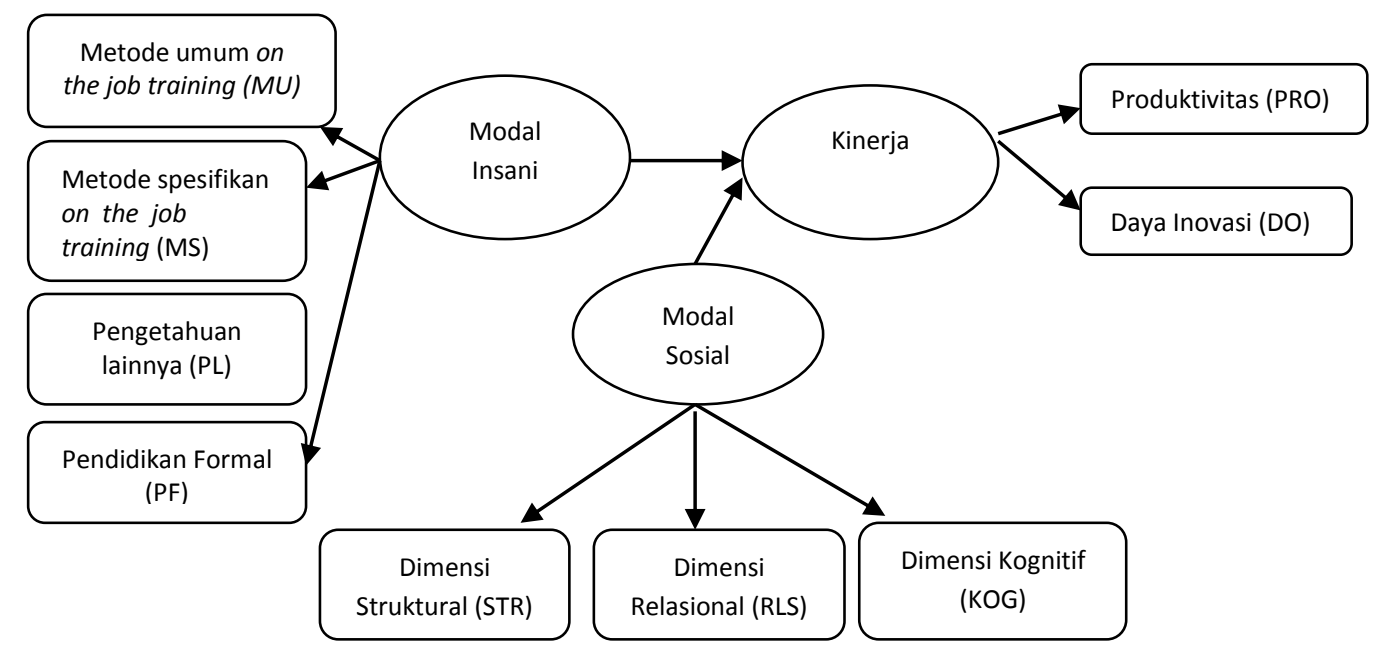

Gambar 3. Struktur model kedua

Berdasarkan pada kedua model tersebut didapatkan hipotesis yang diajukan untuk penelitian ini yaitu sebagai berikut:

$\mathrm{HO}_{1,2,3}$ : Tidak ada pengaruh modal insani dan modal sosial terhadap kinerja UKM $\mathrm{H}_{1,2,3}$ : Terdapat pengaruh modal insani dan modal sosial terhadap kinerja UKM 


\section{Hasil dan Pembahasan}

III.1. Karakteristik UKM

Pada penelitian ini sampel UKM Makanan dan Minuman Kota Bogor berjumlah 13 UKM dengan kriteria tenaga kerja minimal berjumlah 5 orang. Karakteristik UKM yang menjadi responden penelitian ini ditunjukan pada Tabel 1.

Tabel 1. Responden penelitian UKM makanan dan minuman Kota Bogor

\begin{tabular}{|c|c|c|c|c|c|}
\hline Nama UKM & $\begin{array}{l}\text { Tahun } \\
\text { Berdiri }\end{array}$ & $\begin{array}{c}\text { Skala } \\
\text { Usaha }\end{array}$ & Jenis Usaha & $\begin{array}{c}\text { Jumlah } \\
\text { Tenaga } \\
\text { Kerja }\end{array}$ & Omset (Rp) \\
\hline 1. Bolu pisang ibu onih & 20 & Kecil & Bolu pisang & 9 & 50000000 \\
\hline 2. Mitra makmur & 14 & menengah & Minuman jelly & 66 & 800000000 \\
\hline 3. Brownies el-sari & 10 & Kecil & Brownis dan bolu & 11 & 100000000 \\
\hline 4. Sahazah krupuk & 3 & Kecil & Krupuk & 18 & 44000000 \\
\hline 5. Anofood prima nusantara & 14 & menengah & Gepuk dan catering & 30 & 600000000 \\
\hline 6. Risollaku & 3 & Kecil & Risol & 5 & 35000000 \\
\hline 7. Papa pia & 4 & Kecil & Pia & 10 & 12500000 \\
\hline 8. Akazia cake $n$ bakery & 6 & Kecil & Kue kering & 6 & 30000000 \\
\hline 9. Dodol talas & 10 & Kecil & Dodol talas & 6 & 6000000 \\
\hline 10. 3-roses & 5 & Kecil & $\begin{array}{l}\text { Kue kering, pia, dan } \\
\text { roti }\end{array}$ & 18 & 70000000 \\
\hline 11. Asih aulia & 10 & Kecil & Kue kering & 7 & 11000000 \\
\hline 12. Cielo & 3 & Kecil & Minuman sirup pala & 12 & 135000000 \\
\hline 13. Simping dewi & 43 & Kecil & Simping & 5 & 35000000 \\
\hline
\end{tabular}

Tabel 1 menunjukan bahwa UKM Makanan dan Minuman Kota Bogor memiliki karekteristik yang cukup bertahan karena 7 dari 13 sampel UKM telah berdiri selama lebih dari 10 tahun. Berdasarkan data di lapangan, pemilik UKM telah ahli dalam mengenal pasar sehingga persaingan usaha terlihat cukup baik dengan aneka ragam kuliner berbeda dan unik yang ditawarkan kepada konsumen oleh tiap UKM. Inovasi tersebut dapat berupa bentuk, kemasan, dan rasa. Inovasi tersebut dapat mendatangkan omset usaha rata-rata UKM mencapai di atas Rp 30000000 per bulan.

Terlihat pula bahwa UKM makanan dan minuman mampu menyerap tenaga kerja, usaha kecil mampu menyerap 5-8 tenaga kerja, sedangkan usaha menengah mencapai 66 tenaga kerja dan menghasilkan omset tertinggi sebesar Rp 800000000. Meskipun tenaga kerja di UKM tidak mempermasalahkan mengenai pendidikan namun pemerintah Kota Bogor membekali keterampilan tenaga kerja dengan adanya pelatihan.

\section{III.2. Karakteristik Tenaga Kerja}

Tenaga kerja yang dijadikan responden berjumlah 60 orang dari 13 UKM yang dipilih melalui teknik purposive sampling. Pendidikan tenaga kerja UKM makanan dan minuman Kota Bogor terbanyak pada tingkat SMA. Setara dengan hal tersebut usia tenaga kerja terbanyak pada rentang 16-25 tahun yang mana usia tersebut termasuk dalam kategori usia produktif dan siap bersaing di dunia kerja. Setiap UKM memiliki kriteria tertentu dalam memberikan kompensasi terhadap karyawannya. Penghasilan yang diperoleh karyawan UKM berdasarkan pada keterampilan yang dimiliki, hasil kerja, dan kemampuan dalam bekerja. Rata-rata pendapatan karyawan berada pada 
rentang Rp 1000001 sampai Rp 1500 000. Pendapatan tersebut berada di atas UMK kota Bogor tahun 2012 sebesar Rp 1174 200. UKM telah merekrut tenaga kerja dengan profesional dan rata-rata tenaga kerja UKM tidak memiliki hubungan keluarga dengan pemilik. Namun, pada umumnya UKM makanan dan minuman belum menerapkan struktur organisasi formal dan manajemen dipimpin langsung oleh pemilik. Akibatnya, tingkat turn over karyawan menjadi cepat yaitu berkisar antara 0-3 tahun.

III.3. Persepsi Tenaga Kerja UKM terhadap Modal Insani, Modal Sosial, dan Kinerja UKM

Persepsi adalah penilaian yang diajukan seseoerang sebagai bentuk pencapaian yang diraih. Penilaian persepsi karyawan UKM terhadap variabel modal insani, modal sosial, dan kinerja dapat dilihat pada Tabel 2.

Tabel 2. Persepsi karyawan UKM terhadap modal sosial, modal insan, dan kinerja

\begin{tabular}{|c|c|c|c|}
\hline No & Variabel & Nilai & Keterangan \\
\hline \multicolumn{4}{|c|}{ Modal Sosial } \\
\hline 1 & Dimensi Struktural & 3.90 & Setuju \\
\hline 2 & Dimensi Relasional & 4.05 & Setuju \\
\hline 3 & Dimensi Kognitif & 3.90 & Setuju \\
\hline \multicolumn{4}{|c|}{ Modal Insani } \\
\hline 1 & Pendidikan Formal & 3.28 & Cukup Setuju \\
\hline 2 & Metode umum on the job training & 3.46 & Setuju \\
\hline 3 & Metode spesifik on the job training & 3.46 & Setuju \\
\hline 4 & Pengetahuan Lain & 3.69 & Setuju \\
\hline \multicolumn{4}{|c|}{ Kinerja } \\
\hline 1 & Produktivitas & 3.86 & Setuju \\
\hline 2 & Daya Inovasi & 4 & Setuju \\
\hline
\end{tabular}

Keterangan: Angka yang bercetak tebal merupakan nilai terbesar

Berdasarkan Tabel 2, karyawan setuju akan adanya pengaruh sosial terhadap kinerja yang dihasilkan dengan nilai terbesar 4.05 pada dimensi relasional. Hasil dari masing-masing indikator menunjukan nilai setuju, artinya modal sosial perlu dipertahankan kondisinya. Pada variabel modal insani terlihat bahwa pendidikan formal memiliki nilai yang rendah. Hal ini menandakan bahwa pendidikan formal dianggap sebagai sesuatu yang tidak penting bagi karyawan, bagi pemilik yang terpenting adalah keterampilan atau keahlian yang dimiliki untuk menekuni suatu bidang. Adapun penilaian kinerja paling disetujui oleh karyawan adalah daya inovasi sehingga karyawan berkenan untuk merubah cara kerja untuk mengaplikasikan inovasi agar tujuan UKM dapat tercapai.

\section{III.4. Importance-Performance Analysis (IPA)}

IPA terdiri atas dua komponen, yaitu analisis kuadran dan analisis kesenjangan (gap). Analisis kuadran akan memetakan atribut yang diplotkan berdasarkan tingkat kepentingan dan kinerja, sedangkan analisis kesenjangan digunakan untuk melihat kesenjangan antara harapan dengan kinerja yang dicapai oleh atribut terkait (Supranto 2004). Analisis kuadran dengan diagram kartesius digunakan untuk memetakan atibut- 
atribut kinerja dan kepentingan /harapan yang telah dianalisis ditunjukan pada Tabel 3.

Tabel 3.Analisis kuadran dan analisis kesenjangan IPA

\begin{tabular}{llcccc}
\hline No & \multicolumn{1}{c}{ Variabel } & Kinerja $(\mathbf{x})$ & $\begin{array}{c}\text { Kepentingan } \\
(\mathbf{y})\end{array}$ & $\begin{array}{c}\text { Tingkat } \\
\text { kesesuaian } \\
\text { (Tki\%) }\end{array}$ & Gap \\
\hline 1 & Laporan keuangan & 3.69 & 4.46 & 82.76 & -0.77 \\
2 & Pencatatan keuangan harian & 3.62 & 4.46 & 81.03 & -0.85 \\
3 & Sarana prasarana & 3.31 & 4.08 & 81.13 & -0.77 \\
4 & Standar pelaksanaan produksi & 3.38 & 4.08 & 82.89 & -0.7 \\
5 & Standar mutu & 3.85 & 4.17 & 92.31 & -0.32 \\
6 & Sistem pengendalian mutu & 3.38 & 4.08 & 82.89 & -0.7 \\
7 & Inovasi produk & 3.62 & 4.17 & 86.77 & -0.55 \\
8 & Inovasi teknik produksi & 3.54 & 4.08 & 86.66 & -0.54 \\
9 & Target pasar & 3.77 & 4.17 & 90.46 & -0.4 \\
10 & Promosi produk & 3.46 & 4.17 & 83.08 & -0.71 \\
11 & Jaringan distribusi & 3.92 & 4.42 & 88.82 & -0.49 \\
12 & Administrasi SDM & 3.15 & 3.92 & 80.39 & -0.77 \\
13 & Pelatihan SDM & 3.15 & 3.69 & 85.42 & -0.54 \\
14 & Sistem kompensasi & 3.69 & 4.08 & 90.57 & -0.38 \\
15 & Rencana jangka pendek & 3.62 & 3.92 & 92.16 & -0.31 \\
16 & Rencana jangka menengah & 3.46 & 3.92 & 88.24 & -0.46 \\
17 & Rencana jangka panjang & 3.23 & 3.92 & 82.35 & -0.69 \\
18 & Visi usaha terdokumentasi & 2.31 & 3.85 & 60.00 & -1.54 \\
19 & Misi usaha terdokumentasi & 2.31 & 3.85 & 94.00 & -1.54 \\
20 & Tujuan usaha & 3.62 & 3.85 & 84.62 & -0.23 \\
21 & Budaya organisasi & 3.38 & 4 & 80.77 & -0.62 \\
22 & Struktur organisasi formal & 3.23 & 4 & $\mathbf{1 8 3 7 . 3}$ & $\mathbf{- 1 4 . 6 4}$ \\
\hline Jumlah & $\mathbf{7 4 . 6 9}$ & $\mathbf{9 3 . 3 9}$ & $\mathbf{8 3 . 5 1}$ & $\mathbf{- 0 . 6 6}$ \\
\hline Rata-rata & $\mathbf{3 . 4 6}$ & $\mathbf{4 . 0 6}$ & & \\
\hline
\end{tabular}

Berdasarkan Tabel 3, dapat diketahui bahwa tingkat kepuasan sebesar 83.51 artinya kepuasan tinggi. Adanya kesenjangan antara harapan dan kinerja sebesar -0.66 menunjukan bahwa kinerja kurang dari harapan yang dipersepsikan. Sejalan dengan itu, rata-rata harapan lebih besar dibanding dengan rata-rata kinerja. Selanjutnya, dengan adanya analisis kuadran dapat diketahui indikator yang akan menjadi prioritas untuk dikembangkan. Prioritas tersebut dapat dilihat melalui Gambar 4.

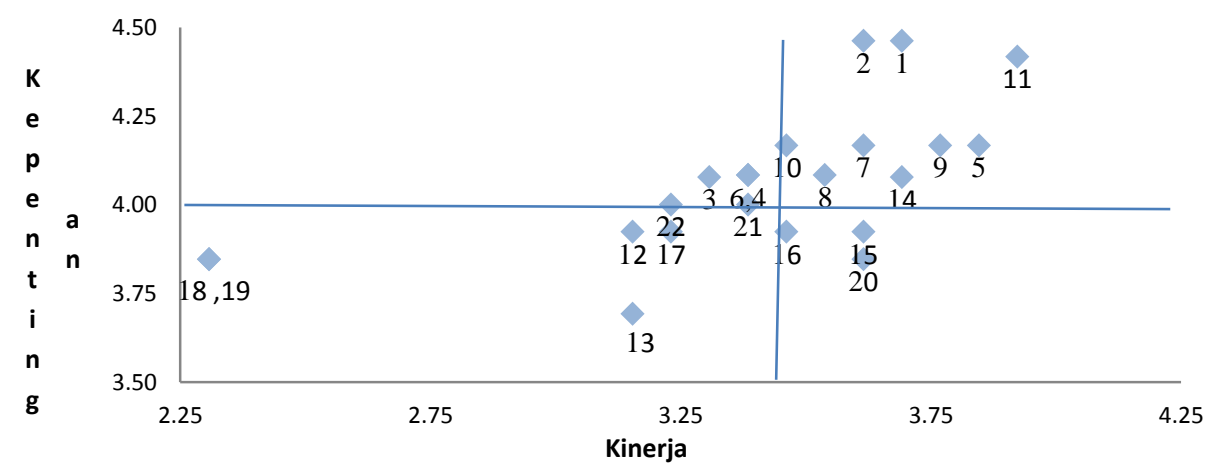

Gambar 4. Diagram kartesius IPA 
Seluruh variabel yang telah ditentukan akan tersebar ke empat bagian dalam kuandran analisis pada Gambar 4. Penyebaran variabel-variabel penelitian dijelaskan sebagai berikut:

a. Kuadran I (Prioritas utama)

Variabel-variabel di bagian ini memiliki tingkat kinerja di bawah rata-rata tetapi tingkat kepentingan tinggi. Variabel yang masuk ke dalam kuadran I adalah variabel $: 3,4,6,21,22$

b. Kuadran II (Pertahankan kinerja)

Variabel-variabel ini memiliki tingkat kepentingan yang tinggi dan kinerja yang diatas rata-rata. Variabel-variabelnya adalah 1, 2, 5, 7, 8, 9, 10, 11, 14

c. Kuadran III (Prioritas rendah)

Variabel-variabel ini memiliki tingkat kepentingan cukup rendah dan kinerjanya juga dinilai rendah. Variabelnya adalah variabel: 12, 13, 17, 18, 19

d. Kuadran IV (Kinerja berlebihan)

Variabel-variabel ini memiliki tingkat kepentingan cukup rendah tetapi kinerja cukup tinggi, sehingga dianggap berlebihan oleh pemilik. Pada kuadran ini, fokus sumber daya dapat dialihkan ke variabel lain yang lebih diprioritaskan. Variabel yang termasuk kuadran ini adalah variabel $15,16,20$

\section{III.5. Permasalahan di UKM}

Diagram tulang ikan menggambarkan rincian permasalahan utama yang dihadapi oleh UKM Makanan dan Minuman Kota Bogor. Kepala ikan melambangkan akibat dari berbagai permasalahan, duri melambangkan penyebab pendukung dari permasalahan utama, dan ekor melambangkan penyebab utama. Gambar 5 di bawah ini akan menggambarkan berbagai permasalahan tersebut.

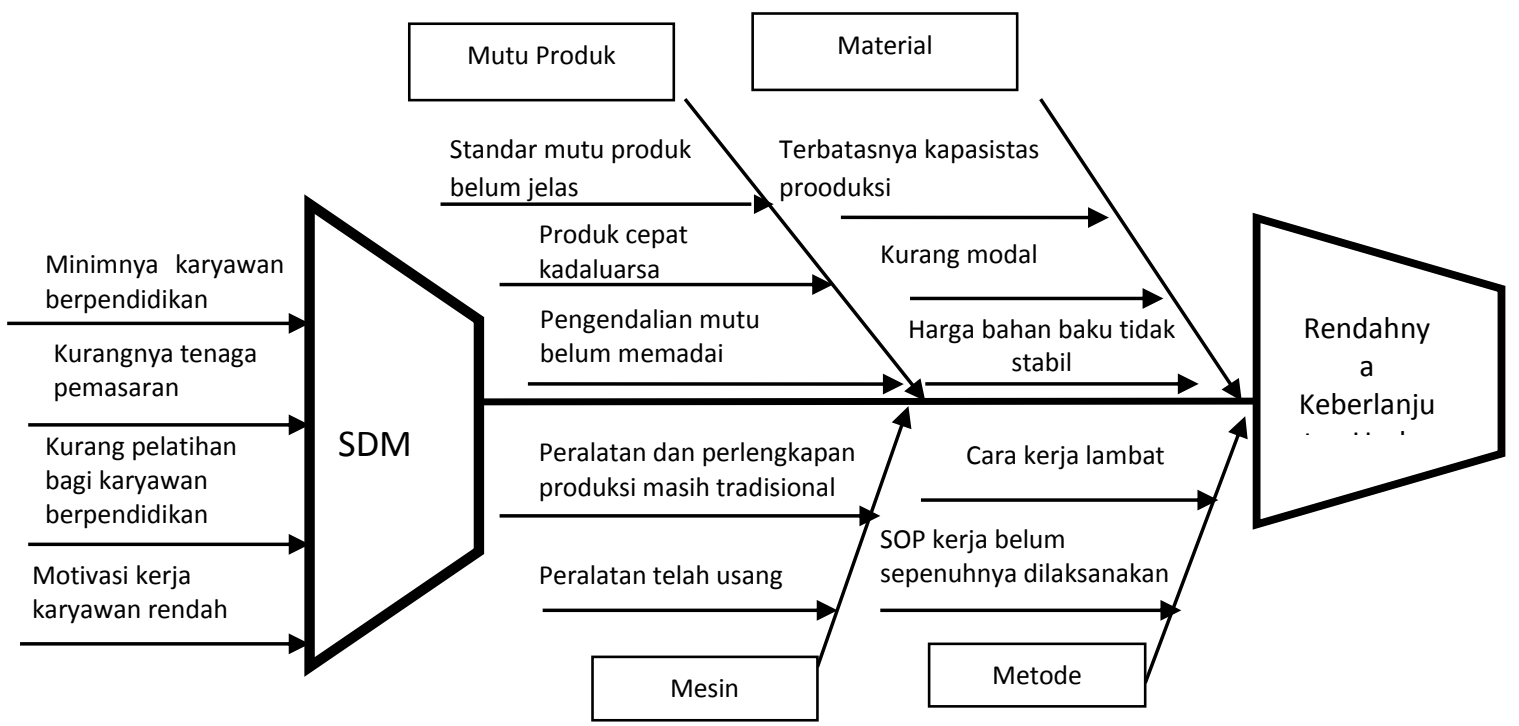

Gambar 5. Diagram tulang ikan

Penyebab utama permasalahan UKM adalah manusia. Manusia berpengaruh penting terhadap keberlanjutan usaha dan keunggulan daya saing. Minimnya tenaga kerja yang berpendidikan dan kurangnya pelatihan keterampilan terhadap karyawan 
menyebabkan UKM sulit untuk maju. Penyebab kedua adalah rendahnya mutu produk. Hal ini berpengaruh besar pada kepuasan konsumen dan kepercayaan terhadap UKM tersebut. UKM di Bogor khususnya makanan dan minuman memiliki kendala dalam mutu produk yaitu produk cepat kadaluarsa. Keadaan tersebut tidak didukung adanya pengendali mutu yang memadai dan tidak adanya standar mutu yang jelas.

Keadaan di lapangan ditemukan, bahwa beberapa UKM masih menyatukan rumah pribadi dengan tempat produksi sehingga terdapat keterbatasan dalam kapasitas produksi. Peralatan dan perlengkapan produksi juga masih tradisional. Penyebab keempat yaitu ditinjau dari segi material. Material merupakan seluruh bahan yang diperlukan untuk melakukan suatu proses di organisasi. Penyebab dikeluhkan oleh para pelaku usaha adalah sosialisasi khusus dari perguruan tinggi. Bogor memiliki salah satu universitas terbaik negeri yang menjadi harapan bagi pelaku usaha agar usahanya mudah untuk berkembang. Namun, pada kenyataannya sosialisasi mengenai informasi pelatihan yang dibutuhkan UKM baik itu keamanan mutu, gizi, sertifikasi halal, dan lain-lain, belum sampai kepada pemilik usaha. Dalam hal ini dibutuhkan integrasi sistem informasi yang tepat antara perguruan tinggi dan UKM.

III.6. Analisis Pengaruh Modal Insani dan Modal Sosial terhadap Kinerja UKM dengan Pendekatan Partial Least Square (PLS)

Alat analisis yang digunakan adalah SEM dengan pendekatan Partial Least Square (PLS) yang diolah dengan SmartPLS. Evaluasi model dilakukan untuk melihat pengaruh variabel eksogen terhadap variabel laten endogen serta menentukan model terbaik dari kedua model penelitian. Secara umum, evaluasi dan interpretasi dari ketiga model dapat dilihat pada Tabel 4.

Tabel 4. Hasil evaluasi outer model dan inner model model 1 dan 2

\begin{tabular}{|c|c|c|c|}
\hline Kriteria & Standar penilaian & Model 1 & Model 2 \\
\hline Loading factor & $\begin{array}{l}\text { Nilai loading factor }> \\
0.7\end{array}$ & $\begin{array}{l}\text { Nilai loading factor PL, } \\
\text { KOG, STR, DO, PRO diatas } \\
0.7\end{array}$ & $\begin{array}{l}\text { Nilai loding factor KOG, } \\
\text { RLS, STR, PL, PRO, DO diatas } \\
0.7\end{array}$ \\
\hline $\begin{array}{l}\text { Average } \\
\text { Variance } \\
\text { Extracted }\end{array}$ & Nilai AVE > 0.50 (Valid) & $\begin{array}{l}\text { m. insani }(1.0000), \text { m.sosial } \\
(0.7916) \text {, kinerja }(0.6373)\end{array}$ & $\begin{array}{l}\text { m. insani }(1.0000), \text { m.sosial } \\
(0.6326) \text {, kinerja }(0.6512)\end{array}$ \\
\hline Communlity & Nilai > 0.5 (Valid) & $\begin{array}{l}\text { m. insani }(1.0000), \text { m.sosial } \\
(0.7916) \text {, kinerja }(0.6373)\end{array}$ & $\begin{array}{l}\text { m. insani }(1.0000), \text { m.sosial } \\
(0.6326) \text {, kinerja }(0.6512)\end{array}$ \\
\hline $\begin{array}{l}\text { Composite } \\
\text { Reliability }\end{array}$ & $\begin{array}{l}\text { Composite Reliability > } \\
0.7 \text { (Reliabel) }\end{array}$ & $\begin{array}{l}\text { M. insani }(1.0000), \mathrm{m} \text {. } \\
\text { sosial }(0.8856), \text { kinerja } \\
(0.7781)\end{array}$ & $\begin{array}{l}\text { M. insani }(1.0000), \mathrm{m} \text {. } \\
\text { sosial }(0.8477), \text { kinerja } \\
(0.7729)\end{array}$ \\
\hline Signifikansi & $\begin{array}{l}\text { Nilai T-Statistik > } 1.96 \\
(5 \%)\end{array}$ & $\begin{array}{l}\text { Insani>>kinerja } \\
\text { (5.0174)(Berpengaruh) } \\
\text { Sosial >> Kinerja } \\
(2.6150)(\text { Berpengaruh) } \\
\text { Sosial - > insani (2.9148) }\end{array}$ & $\begin{array}{l}\text { Insani - >Kinerja (5.4875) } \\
\text { (Berpengaruh) } \\
\text { Sosial >> Kinerja (5.4310) } \\
\text { (Berpengaruh) }\end{array}$ \\
\hline R-Square & $\begin{array}{l}R \text {-square menunjukan } \\
\text { tingkat kekuatan } \\
\text { model }\end{array}$ & $\begin{array}{l}R \text {-square kinerja sebesar } \\
0.1067 \text { insani } 0.1164\end{array}$ & $\begin{array}{l}R \text {-square kinerja sebesar } \\
0.2998\end{array}$ \\
\hline
\end{tabular}


Berdasarkan Tabel 4, nilai hasil SEM tersebut mampu mengevaluasi dan menentukan model terbaik untuk menjadi model penelitian dan menjawab hipotesis. Hasil evaluasi dari kedua model menunjukan bahwa terdapat indikator yang direduksi, namun pada model kedua indikator yang direduksi lebih sedikit. Uji valid dan reliabel model menggunakan nilai AVE, Communlity, dan Composite Reliability. Pada kedua model sudah memenuhi kriteria valid dan reliabel. Hasil analisis inner dari model 1 dapat dilihat pada Gambar 6.

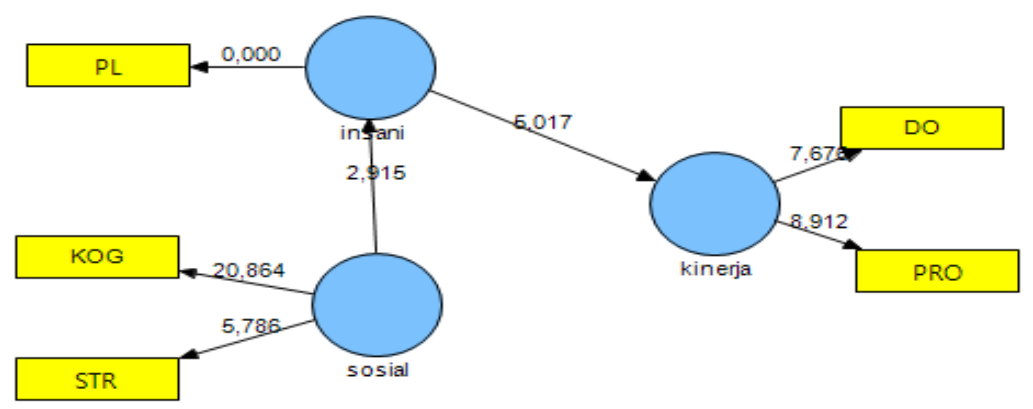

Gambar 6. Hasil inner model 1

Berdasarkan Gambar 6, diketahui bahwa indikator terpilih yang merefleksikan modal sosial antara lain dimensi struktural dan dimensi relasional. Indikator yang merefleksikan modal insani yaitu pengetahuan lain. Pada variabel kinerja indikator yang merefleksikan adalah daya inovasi dan produktivitas. Uji hipotesis untuk model 1 diketahui dengan membandingkan nilai t-statistik/t-hitung dengan t-tabel (1.96) dapat dilihat pada Tabel 5.

Tabel 5. Nilai koefisien dan t-hitung model 1

\begin{tabular}{lcccc}
\hline \multicolumn{1}{c}{ Alur } & Original Sample & Standard Error & T-Statistik & Evaluasi model \\
\hline Insani $\rightarrow$ Kinerja & 0.326 & 0.065 & 5.017 & signifikan \\
Sosial $\rightarrow$ Insani & -0.341 & 0.117 & 2.914 & signifikan \\
\hline
\end{tabular}

Nilai koefisien Tabel 5 menjawab hipotesis yang diajukan pada penelitian yaitu modal insani memiliki pengaruh positif dan signifikan terhadap kinerja UKM ditujukan dengan nilai thitung (5.017) > t-tabel (1.96). Nilai negatif pada original sampel menunjukan bahwa modal sosial tidak berpengaruh langsung terhadap kinerja, namun berpengaruh signifikan terhadap modal insani sehinggaTerima $\mathrm{H} 1_{1}$. Selanjutnya, analisis hubungan pengaruh untuk model 2 ditunjukan oleh Gambar 7.

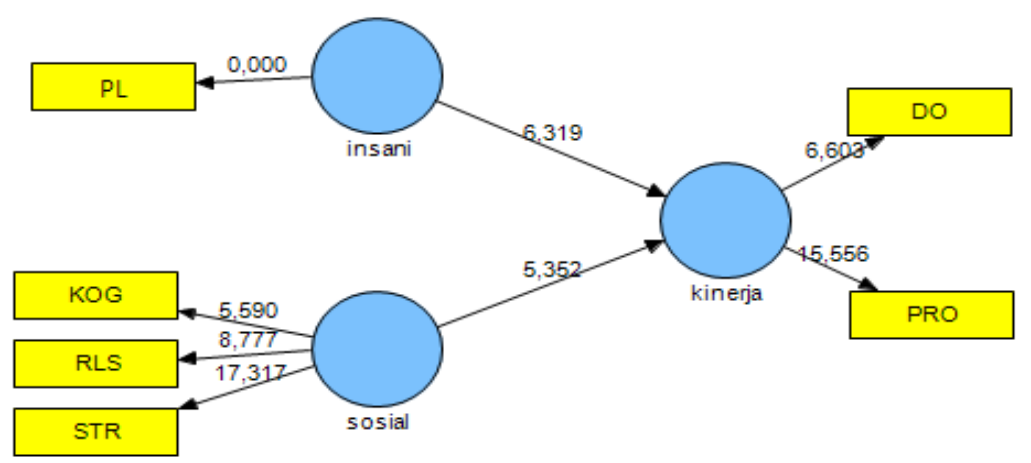

Gambar 7. Hasil inner model 2 
Berdasarkan Gambar 7, diketahui bahwa terdapat pengaruh modal insani dan modal sosial terhadap kinerja UKM. Adapun indikator yang merefleksikan modal sosial antara lain dimensi struktural, dimensi relasional, dan kognitif. Indikator yang merefleksikan modal insani hanya pengetahuan lain. Pada kinerja indikator yang merefleksikan adalah daya inovasi dan produktivitas. Nilai dari pengaruh tersebut dan uji hipotesis dapat dilihat nilai koefisien pada Tabel 6.

Tabel 6. Nilai koefisien dan t-hitung model 2

\begin{tabular}{ccccc}
\hline Alur & Original Sample & Standard Error & T-Statistik & Evaluasi model \\
\hline Insani $\rightarrow$ kinerja & 0.411883 & 0.075057 & 5.487572 & Signifikan \\
Sosial $\rightarrow$ kinerja & 0.447438 & 0.082384 & 5.431095 & Signifikan \\
\hline
\end{tabular}

Nilai koefisien Tabel 6 menjawab hipotesis yang diajukan pada penelitian yaitu :

a) Terima $\mathrm{H}_{2}$, ditunjukan dari t-hitung (5.431095) > t-tabel (1.96) artinya modal sosial berpengaruh positif dan signifikan terhadap kinerja.

b) Terima $\mathrm{H}_{3}$, ditunjukan dari t-hitung (5.487572) > t-tabel (1.96) artinya modal insani berpengaruh positif dan signifikan terhadap kinerja.

Jika dibandingkan antara model 1 dan model 2, maka dapat dinyatakan bahwa nilai T-statistik dan R-square model dua mempunyai nilai yang lebih besar. Maka, model dua adalah model terpilih dalam penelitian ini. Selanjutnya model 2 dapat digunakan sebagai pertimbangan dalam pembuatan implikasi manajerial.

\section{III.7. Implikasi Manajerial}

Hasil analisis baik secara deskriptif maupun dengan SEM SmartPLS menunjukan bahwa modal insani dan mosal sosial berpengaruh positif terhadap kinerja. Maka, kegiatan yang mendukung meningkatnya kualitas modal insani dan modal sosial perlu dilakukan program penunjang. Tabel 7 berikut menunjukan indikator terpilih melalui penilaian SEM, analisis deskriptif, dan analisis IPA yang menjadi acuan dalam pembuatan program UKM.

Tabel 7. Indikator terpilih dalam penilaian alat analisis

\begin{tabular}{|c|c|c|c|}
\hline Indikator & Analisis Deskriptif & Analisis SEM & Analisis kepentingan-kinerja \\
\hline Modal insani & Pengetahuan lain & Pengetahuan lain & 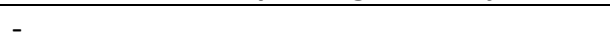 \\
\hline Modal sosial & Dimensi relasional & $\begin{array}{l}\text { Dimensi } \\
\text { struktural }\end{array}$ & $\begin{array}{l}\text { Budaya organisasi, struktur organisasi } \\
\text { formal }\end{array}$ \\
\hline Kinerja & Daya Inovasi & Daya Inovasi & $\begin{array}{l}\text { Sistem pengendalian mutu, standar } \\
\text { pelaksanaan produksi }\end{array}$ \\
\hline $\begin{array}{l}\text { Faktor } \\
\text { pendukung }\end{array}$ & - & - & Sarana prasarana \\
\hline
\end{tabular}

Berdasarkan Tabel 7, beberapa indikator terpilih tersebut dijadikan acuan sebagai pembuatan rekomendasi program penunjang kemajuan UKM. Untuk menghasilkan kinerja yang baik, maka UKM membutuhkan sistem yang baik. Sistem ini bukan hanya berupa peraturan atau standar melainkan melibatkan pihak-pihak terkait langsung yaitu sumber daya manusia. Salah satu sistem manajemen yang menawarkan suatu disiplin yang memperlakukan intelektual sebagai aset adalah knowledge 
management yang diukur dengan tiga variabel yaitu personal knowledge, job procedure, dan technology (Honeycutt 2005).

Dalam hal ini, Personal knowledge membutuhkan pengetahuan lain yang dimiliki individu, dimensi relasional, dan dimensi struktural, sehingga dapat membentuk inovasi. Pengetahuan lain adalah pengetahuan yang diperoleh dari berbagai sumber sehingga dapat membentuk personal knowledge. Praktek membentuk personal knowledge dapat dilakukan melalui mengomunikasikan pengalaman kerja dengan rekan kerja. Pemilik/manajer membentuk forum diskusi secara rutin untuk menyampaikan pendapat, ide, kritikan, dan komentar dari para karyawan. Kegiatan forum diskusi difokuskan untuk meningkatkan kinerja. Pembahasan diskusi dapat mengenai metode pemasaran (internet marketing, pelatihan personal branding, strategi marketing melalui promosi) dan metode produksi (peningkatan mutu produk dan keselamatan keamanan kerja). Pada metode pemasaran mensyaratkan bahwa semua karyawan (divisi) bekerja bersama-sama dengan perusahaan sebagai tim untuk melayani pelanggan, sehingga dapat meningkatkan penjualan dengan konsep pemasaran yang telah disepakati.

Tanggung jawab karyawan pun dapat diuji dengan adanya Standar Operational Procedure (SOP). SOP berisi standar pelaksanaan produksi dan sistem pengendalian mutu. Donoghue et al. dalam Kosasih (2007) mengemukakan bahwa knowledge management yang efektif membutuhkan kombinasi dari berbagai macam elemen organisasi contohnya teknologi dengan praktisi sumber daya manusia, struktur organisasi dan budaya dalam artian untuk memastikan bahwa pengetahuan yang benar diperlukan untuk bertahan pada saat yang tepat. Selanjutnya, rekomendasi yang diajukan yaitu memperbaiki sarana dan prasarana yang dimiliki oleh UKM. Perbaikan sarana dan prasarana bertujuan untuk meningkatkan kapasitas produksi dan mempercepat cara kerja produksi, dan menghasilkan mutu produk tinggi.

Diharapkan program-program rekomendasi tersebut dapat menjadi pemacu bagi UKM makanan dan minuman sebagai jalan menuju UKM berkinerja unggul. Pengusaha juga perlu untuk memperluas jaringan bisninya.Semakin banyak pengusaha tergabung dalam kelompok atau organisasi semakin luas pula jaringannya (Prasetyo dan Harjanti 2013). Mengenai faktor-faktor penghambat keberlanjutan UKM perlu dianalisis kemudian dijadikan sebagai kajian bagi para stakeholder untuk meningkatkan kinerja UKM.

\section{Kesimpulan}

Simpulan dari hasil penelitian Pengaruh Modal Insani dan Modal Sosial Terhadap Kinerja UKM makanan dan minuman Kota Bogor adalah sebagai berikut : 1) Hasil analisis deskriptif pada penelitian ini adalah karyawan menilai bahwa dimensi relasional merupakan dimensi yang paling disetujui dalam membentuk modal sosial. Pengetahuan lain mendapat nilai terbesar yang dianggap paling diprioritaskan dalam membentuk modal insani. Pada kinerja variabel yang paling disetujui adalah daya inovasi; 2) Hasil analisis model 1 menyatakan bahwa modal insani berpengaruh langsung dan signifikan terhadap kinerja dengan modal sosial sebagai variabel moderator. Hasil analisis model 2 menyatakan bahwa modal insani dan modal sosial 
berpengaruh langsung dan signifikan terhadap kinerja; 3) Model terbaik adalah model 2 karena memiliki nilai R-square dan nilai t-statistik yang lebih besar daripada model 1. Sehingga model 2 digunakan sebagai pertimbangan dalam implikasi manajerial.

\section{Daftar Pustaka}

[Dinas Koperasi dan UMKM Kota Bogor] Dinas Koperasi dan Usaha Mikro Kecil dan Menengah Kota Bogor. 2013. Unit Usaha Mikro Kecil dan Menengah Kota Bogor Tahun 2013. Bogor (ID): Dinas Koperasi dan UMKM Kota Bogor.

[Disperindag Kota Bogor] Dinas Industri dan Perdagangan Bogor. 2009. Unit Industri Kecil Besar dan Menengah Tahun 2009. Bogor (ID): Disperindag Kota Bogor.

Honeycutt J. 2005. Knowledge management strategies; Strategi manajemen pengetahuan. Jakarta (ID) : PT. Elex Media Komputindo.

Kosasih N. 2007. Pengaruh Knowledge Management Terhadap Kinerja Karyawan: Studi Kasus Departemen Front Office Surabaya Plaza Hotel. Jurnal Manajemen Perhotelan [internet].[diunduh 2014 Maret 14]; 3(2): 80-88. Tersedia pada: http://cpanel.petra.ac.id/ejournal/index.php/hot/article/viewFile/16753/16733

Kusnedi MS. 2008. Model-model Persamaan Struktural Satu dan Multigroup Sample dengan LISREL. Bandung (ID): CV ALFABETA.

Nahapiet J, Ghoshal S. 1998. Social capital, intellectual capital, and the organizational advantage. Academic of Management Review [internet]. [diunduh 2014 juni 6]; 23(2): 242-266. Tersedia pada: http://staffweb.hkbu. edu.hk/vwschow/lectures /ism3620/rp01.pdf

Nasution MN. 2001. Manajemen Mutu Terpadu (Total Quality Management). Jakarta (ID): Ghalia Indonesia.

Prasetyo T, Harjanti D. 2013. Modal Sosial Pengusaha Mikro dan Kecil Sektor Informal dan Hubungannya Dengan Kinerja Bisnis di Wilayah Jawa Timur. Agora [internet]. [diunduh 2014 Juni 6]; 1(3): 1-4. Tersedia pada: http://Studentjournal. Petra.Ac.Id/Index.Php/Manajemen-bisnis/Article/Viewfile/1146/1035.

Stam W, Elfring T. 2008. Entrepreneurial orientation and new venture performance: the moderating role of intra and extraindustry social capital. Academic of Management journal [internet]. [diunduh 2013 Juni 6]; 51(1): 97-111. Tersedia pada : http://www.business.uconn.edu/ccei/files/Exemplars\%20Conference /Papers/Stam\%20\%26\%20Elfring\%20\%282008\%29\%20EO\%20and\%20social\%20c apital.pdf.

Supranto J. 2004. Analisis Multivariat, Arti dan Interpretasi. Jakarta (ID): Rineka Cipta.

Tambunan T. 2009. UMKM di Indonesia. Cetakan Pertama. Bogor (ID): Ghalia Indonesia.

Umar H. 2003. Metode Penelitian untuk Skripsi dan Tesis Bisnis. Jakarta (ID): PT Raja Grafindo Persada

Wahyuningrum P. 2013. Model Peningkatan Kinerja Usaha Kecil dan Menengah (UKM) Kluster Kerajinan Kota Depok melalui Modal Insani dan Modal Sosial [skripsi]. Bogor (ID): Institut Pertanian Bogor.

Zula JK. 2006. The Development and Initial Assessment of an Instrument for Human Capital Planning [Tesis]. Pennsylvania (US): The Pennsylvania State University. 